\title{
Timely promotion as a motivation factor for job performance among pre-primary school teachers: Observations from Tanzania
}

\section{Okul öncesi öğretmenleri arasında iş performansı için motivasyon faktörü olarak zamanında terfi: Tanzanya'dan gözlemler}

\author{
Laurent Gabriel Ndijuye ${ }^{1}$, Pambas Basil Tandika ${ }^{2}$
}

\begin{abstract}
Article History
Received : 27 January 2019

Revised : 26 April 2019

Accepted : 10 June 2019

Online : 29 July 2019
\end{abstract}

\section{Article Type}

Research Article

\begin{abstract}
The study explored the role of timely promotion as a motivational factor among pre-primary school teachers. Two districts (1 urban affluent and 1 rural poor) were selected. Stratified purposive sampling was used in the selection of 16 schools - 08 from each district; 32 pre-primary school teachers - 04 from each school, and 08 school principals - 01 from each school. Data were collected through interviews, questionnaires and documentary review. Regardless of urbanicity, findings revealed that the primary responsibility of teachers was to ensure children's holistic development. Achievement of this role solely depended on timely promotion and other motivational factors such as the involvement of teachers in decision making, appreciation from educational officers, and good working conditions. It recommends that joint efforts among pre-primary education stakeholders should timely promote teachers, pay their salary arrears, upwardly review teachers' welfare packages, and the conditions of services.
\end{abstract}

Keywords: Pre-primary education; Teacher motivation; Teachers' views; Timely promotion; Job performance; Job satisfaction; Tanzania

Öz: Çalıșma, okul öncesi öğretmenleri arasında zamanında terfinin motivasyon faktörü olarak rolünü imcelemiştir. İki bölge (1 zengin kentsel ve 1 fakir kırsal) seçilmiştir. 16 okulun seçiminde tabakalı amaçlı örnekleme kullanılarak, her iki bölgeden de 8 okul seçilmiş ve her okuldan da 4'er okul öncesi olmak üzere toplamda 32 okul öncesi ögrretmeni; her okuldan 1 tane olmak üzere toplamda 8 okul müdürü seçilmiştir. Veriler, görüşmeler, anketler ve doküman incelemesi yoluyla toplanmıştır. Şehir merkezinden bağımsız olarak, bulgular öğretmenlerin birincil sorumluluğunun çocukların bütünsel gelişimini sağlamak olduğunu ortaya koymuştur. Bu rolün kazanılması yalnızca zamanında terfi ve öğretmenlerin karar alma sürecine dahil olma, eğitim görevlilerinden takdir alma ve iyi çalışma koşulları gibi diğer motivasyonel faktörlere dayanmaktadır. Okul öncesi eğitim paydaşları arasındaki ortak çabaların öğretmenleri zamanında terfi etmeleri, geciktirilmiş maaşların ödemeleri, öğretmenlerin sosyal güvenlik ödeneklerinin ve hizmet koşullarını yükselecek şekilde doğru gözden geçirmeleri önerilmektedir.

Anahtar Kelimeler: Okul öncesi öğretmenleri; Öğretmen motivasyou; Öğretmenlerin görüşleri; Zamanında terfi; İş performansı; İş memnuniyeti; Tanzanya

${ }^{1}$ The University of Dodoma, College of Education, Tanzania, e-mail: buritojr1980@yahoo.com ORCID: https://orcid.org/0000-0001-77126814

${ }^{2}$ The University of Dodoma, College of Education, Tanzania, e-mail: tpambas@gmail.com, ORCID: https://orcid.org/0000-0001-8267-7493

\section{Atıf için/To cite this article:}

Ndijuye, L., \& Tandika, P. (2019). Timely promotion as a motivation factor for job performance among pre-primary school teachers: Observations from Tanzania. Erken Çocukluk Çalssmalar Dergisi, 3(2), 440-456. doi:http://dx.doi.org/10.24130/eccd- 


\section{INTRODUCTION}

In recent years, teachers at all levels of education have been a focus of blame by many stakeholders in Tanzania with regard to job underperformance leading to massive failures of students in public schools (Magina, 2010). Mass failure has been attributed to the growing concerns that teachers in Tanzania are recruited from least qualified cohort (Ottevanger, et al., 2005), timely not promoted (Magina, 2010; Sumra \& Katabaro, 2014), and poor parent-school partnership (Mtahabwa, 2010).

Pre-primary school teachers in Tanzania are not exempted from the stakeholders' concerns (Mwamwenda, 2014). Their job underperformance may be evidenced by an increase of illiteracy among early grades children and increasing number of disciplinary cases among teachers (Uwezo, 2017). Available statistics show that there has been an increase of illiteracy and innumeracy rates in recent years (EQUIP-Tanzania, 2015; Research Triangle Institute [RTI] International, 2014). For instance, available official data indicates that literacy rate declined from 90 percent in 1987 to 69.4 percent in 2011 (the United Republic of Tanzania (URT), 2012).

Further, between 2010 and 2015, primary school children were not acquiring age-appropriate and grade-level skills in Tanzania. (Uwezo, 2010, 2015). Examination results for primary schools and other educational initiatives in the country such as the 2013 Big Results Now indicate that children completed primary education cycle without acquiring basic attitudes, skills, and knowledge required to attain planned learning outcomes and pass the examination (Ministry of Vocational and Training (MoEVT), 2015; RTI-International, 2014; Uwezo, 2017).

However, some policy makers and experts attribute teachers' performance in Tanzania as a result of recruitment of under qualified individuals in the teaching profession (Sumra \& Katabaro, 2014; Uwezo, 2017), and limited use of good performers in schools (Omari, 1995) perpetuating a vicious circle of teachers' job underperformance and eventual students' low performance in the job markets.

\section{Intrinsic and Extrinsic Pre-Primary Teachers' Motivation}

Intrinsic rewards make a pre-primary teacher to forgo high salaries and social recognition to stay in the teaching profession (Dornyei 2004; Jang, 2017). Intrinsic motivation is what that occurs while a person is performing an activity $\mathrm{s} /$ he takes delight and satisfaction in and is seen as internal rewards (Han \& Yin, 2016; Tella 2007). An individual's reaction to work is basic and that one's attitude toward work can very well determine success or failure (Stephen \& Timothy, 2008). 
Intrinsic motivation of a teacher is influenced by factors relating to tasks such as achievement, recognition, advancement and possibility of growth (Jang, 2017).

Extrinsic motivation is an external reward a person enjoys after he finishes his work (Jang, 2017. According to Luthan (1998), extrinsic rewards are defined as "tangible benefit" relating to a job such as salary, fringe benefits, physical conditions, the amount of work, facilities available for doing the work. Extrinsic factors such as organizations policy and administration, technical supervision, personal and interpersonal relations with superiors, peers, and subordinate affect the external motivation of a worker (Dornye, 2004; Han \& Yin, 2016). Extrinsic factors relate to context or setting where the work is performed such as working conditions, job security and interpersonal relationship with superiors and peers (Han \& Yin, 2016; Jang, 2017).

In Tanzania, each public primary school has a pre-primary class attached (MoEVT, 2014). One of the resulting effects of this downward extension of primary education is limited age and levelspecific educational resources at the pre-primary stage. In a context with limited educational resources, pre-primary teachers are looked upon to provide a high job performance (Sifuna, 2007), and educational stakeholders are always curious regarding the job performance of teachers (Dembele \& Lefoka, 2007). Due to limited educational resources allocated for education (UNESCO, 2015), the demands put unlimited measure of teachers' loyalty, devotion, hard work, dedication and commitments (Ubom \& Joshua, 2004; Sifuna, 2007; Hardman, Abd-Kadir \& Tibuhinda, 2012).

Further, the responsibilities and contexts of educations' motivational methods and tools are said to strongly augment productivity which in fact, serves the interests of the educational systems (Cadima, Leal, \& Burchinal, 2010; Darling-Hammond, 2005; Oluchukwu, 2004). Therefore, it implies that educational administrators must devise better methods of determining teachers' needs/interests, practices and means of rewarding and gratifying teachers in case they expect and can be rewarded to have an impact on children's performance (Kivaze, 2000). More importantly, in these contexts characterized with limited educational resources, parental beliefs and support, and teachers' job satisfaction have implications on children's learning outcomes (DarlingHammond, 2005; Rose \& al-Samarrai, 2001).

\section{Timely Promotion and Pre-Primary Teachers' Motivation}

Motivation at a job place is a positive feeling towards work or job (Oluchukwu, 2004). Mwamwenda (2014) and Sumra (2005) establish that in Tanzania, teachers' job dissatisfaction/demotivation may 
lead to absenteeism from schools, aggressive and sometimes violent behavior against learners and fellow teachers, early exits from teaching profession, physical and psychological withdrawal from workplace (Mtahabwa, 2015). Other effects may include poor performance of school in national examinations and international tests (Oluchukwu, 2004), extra-curricular activities, misuse of public fund, highly demoralized and discouraged work force, and students' unrest (Ololube, 2006).

In developed countries, International Institute of Educational Planning [IIEP] (2004), observes that, for the last fifty years, the status of teaching profession has been declining due to dwindling opportunities for teaching incentives, and limited relationship of teachers' performance and development. In particular, Spear (2000) in United Kingdom [UK] supported the conclusion by Herzberg's two-factor model arguing that motivation of teachers and job satisfaction were low due to work overload, low salary and low and sometimes negative societal perception on teachers and teaching profession. Sylvia and Hutchinson (1985); and Deci and Richard (2001) confirm the presence of low teachers' job morale and satisfaction resulting by ineffective pay incentives. Williams (1998) observes that, in some Scandinavian countries, there was high teachers' attrition through leaving teaching profession because of low motivation. Accordingly, the attrition was the result of intellectual ability, age of teachers and education.

Akyeampong and Bannell (2007) revealed that in sub-Saharan Africa, a great number of the existing pre-primary schools were facing an uphill battle of "teachers' motivational crisis". They associate this crisis to existing low accountability, ineffective policy environment and management, low salaries, poor social and occupational status, and poor living conditions. Alarm and Farid (2011) supports the above views as well. Further, Sylvia and Hutchinson (1985), Deci and Richard (2001); and Spear (2000) establishes that teachers' socio-economic status, means by which they made choice and entered the profession, children' behaviours and manners, and syllabus coverage and examination stress were main causes of their motivational crisis. Further, it revealed that personal and social status, classroom environment, socio-economic status, students' behavior, examination stress, rewards and incentives and self-confidence of the teacher affected teachers' motivation. In Guinea, Education Report (2012) indicates that pre-primary teachers' had poor attitudes toward the profession. The poor attitudes were in on issues related to conditions of service - low pay, fringe benefits and other systemic benefits such as professional support, participation in decision making and professional in-service development and training. All these factors affected their motivation. 
In Tanzania, Eshiwani (2013) and Mark (2015) report that good performances in examinations are recorded in such contexts and schools where pre-primary teachers had annually set-up and prepare schemes of work, lesson plans and teaching notes. Further, available empirical evidence advocate that schools should create supportive and motivating working condition for teachers so that they can support holistic children's development and learning. In most cases, pre-primary school teachers' are said not to actively participate in their respective extended families' social events and activities because they insignificantly contribute financially (Lyimo, 2013). This is due to low income received in form of salary that hardly meets their basic needs (Davidson, 2005; Sumra, 2005) and of their extended family members (Mtahabwa, 2010).

Though these issues have been associated with teachers' job underperformance, it is not clear as to what extent they contribute to such underperformance. There was a need therefore, to put in place a systematic and scrutinized study on various views and perspectives associated with pre-primary school teacher motivation. Specifically, this study focused on one factor - timely promotion. In the context of this study, timely promotion entails that pre-primary teachers are not timely paid after formally being promoted and/or are not promoted as they gain job experiences in time. As such, the study intended to achieve the following objectives:

1. To explore pre-primary school teachers' and principal' views and perspectives on the role of timely promotion as a motivation factor in improving children's learning.

2. To suggest strategies for improving teachers' motivational factors which would have to enhanced children's learning attainments in public pre-primary schools.

\section{METHODS}

\section{Sampling Technique and Sample Size}

Given that Dodoma city is a new capital of Tanzania, schools in this rapidly developing city were ideal target population. From the available official district-wise family data, two districts with reported high and low family socio-economic status, were selected. Random sampling was used in the selection of schools

About 16 schools ( 8 from each district) were sampled. A total of 32 pre-primary teachers and 8 school principals were recruited for this study. School principals and teachers were selected by virtue of their positions. It is important to note that in Tanzania, each primary school has a pre- 
primary class attached. As such, a principal for a primary school heads a pre-primary class to which it is attached.

To achieve the objectives of the current study, the selected sample size was large enough to allow triangulation of data sources (Onwuegbuzie, Leech, \& Collins 2012), and data collection methods (Patton, 2009) hence, saturation of analysed data (Creswell, 2012). However, given the existing socio-cultural and political diversities in Tanzania, the selected sample size was not large enough to allow generalization of findings across contexts.

\section{Data Collection Tools and Procedure}

This study used methodological triangulation to collect required data (Creswell, 2012). It triangulated interviews, open-ended questionnaire, and documentary analyses in collecting required data. Preparations of interview guides and questionnaires were constructed to achieve the study objective. Due to its flexibility and time-efficiency, interviews were used with school principals, while the open-ended questionnaire was used with pre-primary school teachers. The interview method was useful in reducing the risk of misinterpretation by informants (Creswell, 2009). It permitted the establishment of rapport and co-operation between the authors and the school principals - immediate supervisors responsible with teachers' timely promotion. This was essential in enabling informants to reveal their views in their own words (Creswell, 2012; Patton, 2009). The process involved face-to-face conversations where information was noted down in the field notebook complimented by a tape recorder. The responses were later compared with responses of other groups in the study.

The study employed questionnaires which were divided into three parts: The first part focused on informants' demographic information such as gender, age, academic qualification and job experiences. The second part dealt with factors influencing teachers' motivation such as timely promotion and remuneration. The third part consisted open-ended items which enabled the authors to probe teachers' suggestions on the most effective strategies that could be utilized to improve their motivation and enhance children's learning.

In this study authors used existing official documents found in the respective schools to understand teachers' motivation. Specifically, the following documents: teachers' attendance books, schemes of work, lesson plans, lesson notes, subject log books, syllabus and sample of children's exercise books. These documents would reveal variations in levels of teachers' motivation between urban and rural teachers. For example, teacher activities as stipulated in the lesson plan may indicate level 
of involvement - which is one of the indicators of their motivation. Least motivated teachers would design classroom activities which require less teacher involvement (Roorda, et al., 2017). Further, the authors observed number of physical resources available and those which had been purchased/ built in the past two years. The targeted resources included number and quality of buildings, human resources, classroom and office furniture and instructional resources. The assumption was that the availability of the said physical materials would motivate teachers to work hard. Documentary review was a very useful method because the said documents could be secured quickly and easily, and covered a wider geographical area and longer reference periods without much cost (Creswell, 2009; Punch, 2005).

\section{Ethical Issues and Parental Consent}

Ethical clearance was obtained from the Office of Research and External Collaboration of the University of Dodoma where the authors are attached. Introduction letter was obtained from the Ministry of Education in Tanzania. Further, the authors had to obtain permission from districts and wards executive officers to access informants. Confidentiality was observed and unauthorized person had no access to the collected data.

\section{Data Analyses}

Collected data were subjected to interpretational analyses which in fact had to involve systematic set of procedures to code and classify qualitative data. This was done to ensure that important constructs, themes and patterns had to emerge. Specifically, the raw data obtained from semistructured interviews and open-ended questionnaire were coded to obtained relevant texts, repeating ideas, themes, theoretical constructs, research concerns and theoretical narratives. It was from repeating ideas that themes and sub-themes were developed. Themes were organized into abstract ideas or theoretical constructs and later developed into theoretical narratives which were used to bridge between the concern of the authors and participants' subjective experiences using their own words.

The criteria that guided analyses of documents and steered the development of the themes were: (a) number of items available, (b) how the information was presented and, (c) the status of the resolution/by-law/decision. The said documents were collected and analyzed by the author. In order to maximize objectivity, communicability, transparency, and coherence techniques were deployed (Auerbach \& Silverstein, 2003). Specifically, the author triangulated data sources, data collection instruments, and bracketed all of his previous understandings, beliefs and assumptions 
during data analyses (Onwuegbuzie, Leech \& Collins, 2012). Further, the process of data analyses was jointly done with two coders.

\section{Inter-rater Reliabilities}

The authors had to train two enumerators with Bachelor of Education (BED) degrees in Early Childhood Education were recruited to assist with data collection and analyses. The authors coded the field notes to classify patterns and constructs of differences in the participants' views. To determine inter-rater reliability, 25 percent of the field notes were coded independently by the authors and coders. The consensus of calculated percentage of agreement among the four raters of the inter-rater reliability was 87 percent.

\section{FINDINGS}

The findings and observations from the study were presented in line with the research objectives following the methods of data collection. These include perceived views on teachers' timely promotion, and strategies for improving teacher's motivation to enhance children's academic performance in public pre-primary schools.

\section{Perceived views on teachers' timely promotion}

The first objective of this study was to solicit information from the pre-primary school principles and teachers' views on the role of timely promotion as a motivation factor in improving children's learning. Teachers' timely promotion was considered critically important in enabling teachers to work effectively. Data were collected using questionnaires supplemented with interviews. Informants revealed that timely promotion was an important motivation factor. In their own words a teacher in School C said:

Teachers who are motivated put much effort in preparing and implementing lessons. For example, in this school teachers who are teaching grade four and seven are given extra allowance of around $20,000 /=$ per week - roughly equivalent to 8 US dollars that has made them highly motivated and pupils are now doing better than they used to be before. Their motivation increased pupils' performance in a way that last year more than $78 \%$ of grade seven pupils were selected to join Secondary schools. Because of delayed promotion by the government, teachers tend to lose interest in working as family costs are greater than our salaries, remember frustrated teacher cannot deliver well teaching and learning objectives. 
These findings point out the relationship between timely promotion, other incentives and allowances at school level and pre-primary school children's learning. Responding to a follow-up question, a teacher in school A commented that,

Timely promoted teachers have positive impact on pupils' learning progress because those who are not promoted put very little efforts in their teaching. Sometimes, pupils are left alone in the classroom the whole day without learning anything. Poor grade promoted teachers also hardly cover the syllabus and this is what is happening in most of public primary schools including Community Secondary Schools. In these schools teachers are not doing enough due to the lack of motivation such as timely promotion.

On the other hand, a Principal of school A revealed that:

Timely promotion plays a great role in increasing teachers' work morale. Most of our teachers in schools they just try to meet the school time table but in the classrooms their efficiencies is very low. So if teachers are motivated through annual increment and timely promotion of their grades they can help the pupils in their studies as well in discipline matters.

In addition, responding an interview question, Principal of school B said that:

Pupils to perform well in both academic and non-academic learning activities, it depends on the level of motivation they get. The more teachers are motivated the more they can do better in the teaching and learning activities that will enhance the pupils' academic performance to be high. For example as a head teacher of this school, I used to motivate them by giving $20,000 /=$ shillings per week (Roughly 8 USD), the fund we raise from the pupils who are in grades 4 and 7 conducting speed test, every mornings before the normal subjects time table.

Furthermore, a Principal of school $\mathrm{H}$ revealed that school management has the role to play as far as teachers' motivation is concerned. On this regard, the School Principal said:

Indeed, as a school Head what I see not only be an effective leader, manager and counselor, but also an effective motivator. Motivated teachers are productive teacher. Also as a school leader I should bear in mind that the use of incentives to motivate teachers in my school is important because the motivated teachers enhance the good academic performance to the pupils.

The authors surveyed documents found in eight (08) School Principals' offices. Items observed by authors were teachers' attendance books, schemes of work, lesson plans, lesson notes, subject log books, syllabus and sample of children's exercise books. The review of the documents the authors intended to see information related to teachers' daily attendance, availability and use of scheme of work, availability and use of lesson notes during teaching process, sequence of teaching and topics 
covered, and teaching process followed. The information obtained in the documents are summarized in Table 1.1 subsequently.

Table 1.1: Documents reviewed

\begin{tabular}{lccl}
\hline Item & Information sought & \% of availability & Main Content \\
\hline Teachers' attendance book & Daily attendances & 80 & Teachers' daily presence \\
Scheme of work & Availability and use & 100 & Biannual lesson activities \\
Lesson plans & Availability and use & 42 & Specific lesson's activities \\
Lesson notes & Availability and use & 41 & Specific lesson's content \\
Subject log book & Sequence and topics covered & 31 Sequence of what has been taught \\
Syllabus & Teaching process to follow syllabus & 70 Sequence of what/how will be taught \\
Pupils' exercise books & Pupils engagement and participation & 35 What children has been taught \\
\hline
\end{tabular}

Source: Field data, (2018)

The Table 1.1 illustrates that $80 \%$ of teachers regularly attended school - weekly attendance. However, $100 \%$ of teachers prepared their schemes of work and used them effectively. Preparations of lesson plans were $58 \%$, although there is a good percentage in availability of scheme of work; the percentage of lesson plans decreased because among other reasons, teachers are discouraged due to lack of timely promotion they expected. This was happening even in the preparation of lesson notes which was $41 \%$.

Given that preparation of lesson plan was relatively low, teachers did not regularly fill-in the subject $\log$ books (31\%). Teaching process that follows syllabus was only $70 \%$, and regular provision of exercises was $60 \%$. By not regularly preparing the above mentioned documents, teachers were abiding to existing teaching code of conduct which requires that they prepare and keep all necessary documents and records. Failure to do may adversely affect regular assessment of job performance, hence their timely promotion.

Strategies for improving teacher's motivation to enhance children's academic performance in public pre-primary schools

The second objective of this study was set to suggest strategies for improving education in public primary schools. Respondents' viewpoints are summarized in the Table 1.2.

Table 1.2: Strategies for improving teacher's motivation to enhance pupils' academic performance in public primary school

\begin{tabular}{lcc}
\hline Strategy & Frequency & Percentage \\
\hline Appreciation & 08 & 08.1 \\
Timely promotion & 54 & 54.5 \\
Improving working condition & 37 & 37.4 \\
Total & $\mathbf{9 9}$ & $\mathbf{1 0 0}$ \\
\hline
\end{tabular}

Source: Field data, (2018) 
From the Table 1.2 it was revealed that $8.1 \%$ of the respondents said that strategies for improving teacher's motivation to enhance pupils' academic performance in public pre-primary school were associated with appreciation of teachers work. More than half (54.5\%) said increasing teachers' salaries was another strategy to improve children's learning. Meanwhile, 37.4\% had the opinion that improving working environment was among the strategies for improving quality of education in public preprimary schools.

Improving working condition of teachers included, provision of teachers' annual increment of their individual salaries, involvement of teachers in decision making, provision of transportation to teachers, ensuring availability of teaching and learning materials, solving teachers' problems on time, and promoting teachers on time are essential contributing factors in improving quality of education in public primary schools. Some of their responses are presented subsequently. Teachers provided different views regarding strategies for improving teacher's working motivation.

A teacher in School F said that:

In fact we need to be recognized, because this is like appreciating our effort in what we have done. To motivate teachers not only in improving our salaries but even to acknowledge those who perform well in teaching activities, at school level, ward level, district level region level even at the national level in the workers' day. I will be happy if one day.

Another teacher in School E pointed-out that:

Our working condition is not good; if this can be improved will be one of the strategies that can motivate teachers in order to improve the pupils' learning outcomes. We do not have staff office that would accommodate us as you see we used to do our works like lesson preparations and marking pupils' exercise books under the shadows of trees or in the classrooms or in the school corridors. Also we used to see a school can be rewarded for good performance, but a school cannot be rewarded without the teachers' effort, so we need to be rewarded for such good performance.

A teacher in School H revealed that:

My friend, you should know how these things work! In fact, teachers as normal beings, their motivation comes from reasonable pay. But as a matter of fact, the current situation is not encouraging. As you might be aware, the salary is low, it is not enough even to incur my monthly expenses. Because of low payment we put ourselves in low class of living standards. So improving the teachers' salaries and other payments could be the strategy in improving the quality of education in our schools. 
The same question asked in the interview conducted to 5 head teachers of 5 primary schools found in Dodoma city and the responses were as follows:

Principal in school E reported that:

Frankly speaking teachers need to be motivated and that will improve the quality education in our school. Most of teachers don't have teaching moral due to low pay which limits their motivation. If you hold other factors constant, teachers' quality and motivation do lead to improved children's performance. Therefore, the strategies that can be useful in improving the quality of education in our school is that, the government has to improve the teachers" payment and has to take a way acknowledge the teachers effort.

School Principal G revealed that:

The government has to ensure availability of enough teaching and learning materials, because available text books for the pupils are not enough given the number of pupils in the classrooms. Also improving schools infrastructure such as staffrooms for the teachers even school principals' offices. Further, it is important get teachers involved in decision making. For example, the paradigm shift from teacher-centred to learner-centred approach, teachers in our school did not attend any in service seminar or training for that. Surprisingly, educational authorities instruct teachers to apply the skills on paradigm shift in teachings.

School Principal A said that:

Teachers' motivation is the result of appreciation of their work. Given the current mass failures of our children, teachers deserve. This can be simply done through different ways such as increasing their pay, provide in-service trainings, responding to their claims, improving their working conditions and providing them an opportunity to access loans with low interest rates.

\section{DISCUSSION and CONCLUSION}

This study intended to solicit information from the pre-primary school principals and teachers' views on the role of timely promotion as a motivation factor in improving children's learning. Further, it aimed to identify pre-primary education stakeholders' suggestions on how to improve pre-primary school teachers' motivation.

\section{Perceived views on teachers' timely promotion}

Findings revealed that pre-primary school teachers' timely promotion significantly motivated them and enhanced children's learning and development. The findings of the current study revealed that 
teachers' timely promotion and motivation in general has a great impact in the pupils' learning progress and outcomes. As motivation increases through improved working environment and timely paying teachers' claims, the level of performance also increases. Findings from the current study concur with those by Mustafa and Othman (2010) who revealed that there is a significant relationship between teachers' motivation and pupils' learning progress and outcomes in Indonesia.

Davidson, (2005) Ratamo (2016) shares that a motivated teacher works happily, fulfilled, devoted and committed in such a way that he/she brings out his/her best in his/her place of work for the learners, parents and the society greatly benefit from his/her services. Though promotion is among the teacher's rights, it indicates in this study that teachers lowered down their working spirit; promotion is among them. However, Armstrong, (2016) and Ratamo, (2016) indicate that teachers who are intrinsically motivated work for the sake of their own, for the provided satisfaction and/or for the acquired feeling of accomplishment and culminating self -actualization. The authors' worries are based on the views that traditional external factors [eg; teacher's salary] may be less important than teacher's work organization (Ottevanger, et al., 2005) and extrinsic rewards may also limit or reduce the effectiveness of intrinsic rewards (Chamberlin, et al., 2002; Frenzel, et al., 2019).

In examining the role of timely promotion to teachers as a motivation factor in improving children's learning, findings indicated that teachers' timely promotion have the great role in increasing the teachers work morale. This observation is aligned with Ottevanger, and colleagues, (2005), Sumra, (2005) who stated that, motivation saves to activate or energize behavior and to give it direction. Armstrong (2008) argues that promotion opportunities build willingness in employees to work, hence stability in school works.

Similarly, Chamberlin and colleagues (2002) revealed that recognition is one of the most significant motivating factor among the industrial workers which enables them to achieve high productivity. They further added that establishment of incentive schemes and wages work as a means of stimulating workers to work hard to be committed and eventually to be satisfied with the motivation they get. And Caprara et al. (2006) suggested that, when teachers are timely promoted/motivated they will love their teaching profession; they will teach effectively that may help the pupils to increase their academic performance.

Strategies for improving teacher's motivation to enhance children's learning progress and performance in public pre-primary schools 
In responding the question on what are the strategies for improving teacher's motivation to enhance pupils' academic performance in public primary school, the findings indicated that, increase of payments. Improving the working environment and appreciating of teachers' effort are among the strategies for improving quality education in public primary schools. It meant that salary and other fridge benefits and incentives are very important strategies for improving pupils' academic performance in public primary school in Tanzania, and in other countries with similar contexts. The two strategies identified by teachers [improving working environment and appreciating them] as important in enhancing child's learning progress concurs with the suggestions made by Akyeampong, and Bennell, (2007). Authors add other essential areas for policy and practice effective in impacting teacher motivation to include accountability of schools and teachers, conflict and security at job place, environmental policy, professional competence, existing vocational commitment and occupational status; improved teachers' working and living conditions, and education system management.

Meanwhile, Guajardo (2011) proposes eight categories of factors that when are in place they determine teacher motivation. Among such factors that are resembles with factors teachers involved in this study mentioned are the remuneration and incentives, working conditions and school environment, and learning materials and facilities. Provision of such factors in school environment ensures teachers are highly satisfied during job (Broekman, 2013; Frenzel, et al., 2019).

\section{CONCLUSION and RECOMMENDATIONS}

In a context of limited educational resources, as it is in most of the public pre-primary classes in Tanzania, quality of teachers is the most important determinant factor for quality of education provided. More importantly, quality of teachers is critically important during the early years of children's education (Darling-Hammond, 2005; Rao, et al., 2013). Therefore, in order for Tanzania to improve quality of education at all levels, it should strategically focus on the quality and wellbeing of pre-primary school teachers.

In addition, pre-primary education stakeholders in Tanzania should focus on pre-primary school teachers by paying attention to what they are doing, listen to what they say, and acknowledge their efforts. Further, to improve their teaching morale, relevant authorities should promote teachers in time and pay their salary dues and other fringe benefits time after promotion. This would greatly motivate teachers, hence improvement of children's learning and progress. 
Given that timely promotion of teachers was not the only motivating factor, it is equally important for pre-primary education stakeholders to create and provide suitable teaching and working conditions such as educational facilities and improved infrastructure such as increased classrooms and reduced class-size for positive teacher-children interaction. If this is done, it will raise the standard of living of the teachers; make the job lucrative and professional nobler which will enhance impetus on the academic performance of pupils.

\section{REFERENCES}

Akyeampong, A, \& Bennell, P. S. (2007). Teacher Motivation in Sub-Saharan and African and South-Asia. London, UK: Department for International Development (DFID). https://assets.publishing.service.gov.uk/media/57a08be640f0b652dd000f9a/Researching theIssuesNo71.pdf

Alarm, T.M. \& Farid S. (2011). Factors affecting teachers' motivation. International journal of business and social sciences, 2(1), 72-92.

Armstrong M. (2016). Armstrong's Handbook of Strategic Human Resource Management. London: Kogan Page

Auerbach, C.F. \& Silverstein, L.B. (2003). Qualitative Data: an introduction to coding and analysis. New York: New York University Press.

Broekman, A. (2013). The rationale and effects of accountability policies on the work and motivation of teachers: Evidence from Indonesia. Global Managerial Education Reforms and Teachers. Brussels: Education International.

Cadima, J., Leal, T., \& Burchinal, M. (2010). The quality of teacher-student interactions: Associations with first graders' academic and behavioral outcomes. Journal of School Psychology, 48, 457-482.

Creswell, J. W. (2009). Research design: A Qualitative, Quantitative and Mixed Method Approaches, 3rd ed., Thousand Oaks CA: Sage Publishers.

Creswell, J. W. (2012). Research design: A Qualitative, Quantitative and Mixed Method Approaches, 4th ed., Thousand Oaks CA: Sage Publishers.

Chamberlin, R., Wragg, T., Haynes, G. \& Wragg, C. (2002). Performance-related pay and the teaching profession: A review of the literature. Research Papers in Education, 17, 31-49.

Davidson, E. (2005). The pivotal role of teacher motivation in Tanzania. HakiElimu Working Papers, Dar es Salaam, Tanzania.

Darling-Hammond, L. (2005). Educating the new educator: teacher education and the future of democracy. The New Educator, 1(1), 1 - 18.

Deci, E. L., \& Richard, R. M. (2001). A motivational approach to self: Integration in personality. In R. Dienstbier (Ed.), Nebraska Symposium on Motivation: Vol. 38. Perspectives on motivation (pp. 237-288). Lincoln: University of Nebraska Press.

Dembele, M. \& Lefoka, P. (2007). Pedagogical renewal for quality universal primary education: Overview of trends in sub-Saharan Africa. International Review of Education, 53, 531-553.

Edge, K., Dapper, E., Stone-Jonson, C., Frayman, K., Terwindt, R., Townsend, J., \& Jeevan, S. (2017) Securing the 21st Century Teacher Workforce: Global perspectives on teacher 
motivation and retention, WISE Research Series. https://www.wiseqatar.org/2017wise- research-21st-century-teacher-workforce

Frenzel, A.C., Taxer, J. L., Schwab, C., \& Kuhbandner, c. (2019). Independent and joint effects of teacher enthusiasm and motivation on student motivation and experiences: A field experiment. Motivation and Emotion, 43(2), 255-265.

Han, J. \& Yin, H. (2016). Teacher motivation: Definition, research development and implications for teachers. Cogent Education, 3(1), DOI: 10.1080/2331186X.2016.1217819

Eshiwani, G.S. (2003). Factors Influencing Performance among Primary and Secondary Pupils in Central Tanzania and Western Province of Kenya. A Policy Study; Nairobi: Nairobi University Press

EQUIP-Tanzania, (2014). Briefing Note 2: Early grade pupil learning in some of the most disadvantaged districts in Tanzania. Country report. Dar es Salaam: Oxford Policy management.

Guajardo, J. (2011). Teacher motivation: Theoretical framework, situation analysis of Save the Children country offices and recommended strategies. Save the Children: Washington, DC.

Hardman, F., Abd-Kadir, J., \& Tibuhinda, A. (2012). Reforming teacher education in Tanzania. International Journal of Educational Development, 32(6), 826-834.

Jang, H.R. (2017). Teachers' intrinsic vs. extrinsic instructional goals predict their classroom motivating styles, Learning and Instruction, 60, 286-300.

Kivaze, J.M. (2000). Evaluation of incentives used for Teachers in secondary Schools in Marakwet District and their influence on performance in KSCE. Unpublished MEd Dissertation, University of Nairobi - Kenya.

Lyimo, J. (2013). The problem of street children in Tan₹ania: a case of Moshi municipality, Kilimanjaro region. Unpublished MEd dissertation, University of Mzumbe, Morogoro.

Mark, J. (2015). Joy at Work at Joy: Living and Working Mindfully Every Day. London: Personhood Press.

Magina, S.B. (2010). The Relationship between Self Ego System, Employer's Responsibility, and Secondary School Teachers' Performance in Tanzania. A Dissertation submitted in partial fulfillment of requirement for the Degree of Master of Arts Education) of the University of Dodoma, Dodoma.

Ministry of Education and Vocational Training. (2015). Basic Education Statistics in Tanzania. Dar es Salaam: Government press.

Mtahabwa, L. (2010). Provision of pre-primary education as a basic right in Tanzania. A reflection from policy documents. Contemporary Issues in Early Childhood, 11(4), 353-364.

Mustafa, M., \& Othman, N. (2010). The effect of work motivation on teacher's work Performance in pekanbaru senior high schools, Riau Province, Indonesia. Sosiohumanika, 3(2), 259-272.

Mwamwenda, T.S. (2014). Early childhood education in Africa. Mediterranean Journal of Social Sciences, 5 (20), 1403-1412.

Ololube, N. (2006). Teachers Job Satisfaction and Motivation for School Effectiveness and Assessment (pp. 6087). University of Helsinki, Organizational Culture and Climate, Thousand Oaks, CA: Sage.

Oluchukwu, R.B. (2004). Challenges of Educational Planning in the 21st Century: In Olagboye, A.A. Fadipe, J.O. (Eds) Management of Nigerian Education: School Project Monitoring and School Plant Maintenance, NIEPA, Ondo.

Onwuegbuzie, A.J., Leech, N.L. \& Collins, K.M.T. (2012). Qualitative analysis techniques for the review of literature. The Qualitative Report, 17(56), 1-28 
Ottevanger, W.J.W., Feiter, L., O-saki, K. M., \& van de Akker, J. (2005). The TEAMS project in Tanzania: From intervention to capacity building, Journal of International Co-operation in Education, $8(1), 111-128$.

Patton, M. Q. (2002). Qualitative Research and Evaluation Methods. (3rd ed). California: Sage Publications.

Patton, M. Q. (2009). An Introduction to Qualitative Research, $4^{\text {th }}$ edition. London: Sage publications ltd.

Punch, K. F. (2005). Introduction to Social Research: Qualitative and Quantitative Approaches, London: Sage Publications.

Ratamo, V. C. (2016). Quality of pre-primary school education: A comparative study of private and public pre-primary school centres in Nairobi city county, Kenya. Unpublished PhD Dissertation, Kenyatta University, Nairobi.

Roorda, D.L., Jak, S., Zee, M., Oort, F.J. \& Koomen, H.M.Y. (2017). Affective TeacherStudent Relationships and Students' Engagement and Achievement: A Meta-Analytic Update and Test of the Mediating Role of Engagement, School Psychology Review, 46(3), 239-261.

Rose, P. \& Al-Samarrai, S. (2001). Household constraints on schooling by gender: empirical evidence from Ethiopia. Comparative Education Review, 45(1), 36-63.

RTI International. (2014). National Baseline Assessment for the 3Rs (Reading, Writing, and Arithmetic) Using EGRA, EGMA, and SSME in Tanzania. Study report. Washington DC: USAID.

Sifuna, D. N. (2007). The challenges of increasing access and improving quality: An analysis of universal primary education interventions in Kenya and Tanzania since the 1970s. International Review of Education, 53, 687-699.

Spear, L.P. (2000). The Adolescent Brain and Age-Related Behavioral Manifestations. Neuroscience and Biobehavioral Reviews, 24, 417-463.

Sumra, S. (2005). The Living and Working Conditions of Teachers in Tanzania. A Research Report. Dar es Salaam: Hakielimu/Tanzania Teachers' Union.

Sumra, S. \& Katabaro, J.K. (2014). Declining quality of education: Suggestions for arresting and reversing the trend. THDR 2014: Background paper No.9. ESRF discussion paper No. 63.

Sylvia, R. D., \& T. Hutchinson. 1985. "What makes Ms. Johnson teach? A study of teacher motivation." Human Relations. 38: 841- 56.

Ubom, I. U. \& Joshua, M. T. (2004) Needs Satisfaction Variables as Predictors of Job Satisfaction of Employees: Implication for Guidance and Counseling. Educational Research Journal,14(3)

UNESCO, (2015). EFA Global Monitoring Report. Education For All 2000-2015: Achievements and challenges. .Retrieved from http://unesdoc.unesco.org/images/0023/002322/232205e.pdf

Uwezo. (2010). Are our Children Learning? Literacy and Numeracy in Tanzania: Annual Learning Assessment Report.Dar Es Salaam: Twaweza East Africa.

Uwezo. (2015). Are our Children Learning? Literacy and Numeracy in Tanzania: Annual Learning Assessment Report.Dar Es Salaam: Twaweza East Africa.

Uwezo. (2017). Are our Children Learning? Literacy and Numeracy in Tanzania: Annual Learning Assessment Report. Dar es Salaam: Twaweza East Africa. 